\title{
Pathological Characterization and Molecular Analysis of Elsinoe Isolates Causing Scab Diseases of Citrus in Jeju Island in Korea
}

J.-W. Hyun, Citrus Experiment Station, National Jeju Agricultural Experiment Station, Rural Development Administration, Jeju-Do, 699-803, Korea; L. W. Timmer, University of Florida, Citrus Research and Education Center, Lake Alfred 33850; and S.-C. Lee, S.-H. Yun, S.-W. Ko, and K.-S. Kim, Citrus Experiment Station, National Jeju Agricultural Experiment Station, Korea

\begin{abstract}
Hyun, J.-W., Timmer, L. W., Lee, S.-C., Yun, S.-H., Ko, S.-W., and Kim, K.-S. 2001. Pathological characterization and molecular analysis of Elsinoe isolates causing scab diseases of citrus in Jeju Island in Korea. Plant Dis. 85:1013-1017.

Two scab diseases are recognized currently on citrus: (i) citrus scab caused by Elsinoe fawcettii, which has several pathotypes; and (ii) sweet orange scab caused by E. australis. Pathogenicity and cultural characteristics among 36 isolates collected from Jeju Island were investigated. Of 30 isolates from satsuma mandarin, yuzu, and kinkoji, all were E. fawcettii; 27 were similar to the Florida broad host range pathotype and 3 were similar to the Florida narrow host range pathotype by inoculation of differential hosts. Six isolates from natsudaidai were nonpathogenic to satsuma mandarin, rough lemon, sour orange, grapefruit, cleopatra mandarin, and natsudaidai leaves, and were only pathogenic to natsudaidai fruit. Isolates from natsudaidai usually produced unique tomentose colonies on potato dextrose agar compared with isolates from other citrus species. The colonies were relatively fast growing, radially sulcate, larger, and more expansive than the gummy, mucoid colonies of other isolates. Isolates from Florida, Australia, Argentina, and Jeju Island (Korea) were genetically differentiated using random amplified polymorphic DNA markers. E. fawcettii from Korea, Florida, and Australia, E. australis from Argentina, and natsudaidai isolates clustered closely within groups, but were clearly distinguishable among groups.
\end{abstract}

Scab diseases of citrus produce fruit blemishes that reduce the value of the fruit for the fresh market and are among the most important diseases reducing farmers' income in Jeju Island, Korea. Three scab diseases were described originally on citrus: (i) citrus scab caused by Elsinoe fawcettii Bitancourt \& Jenk. (anamorph Sphaceloma fawcettii Jenk.); (ii) Tryon's scab caused by S. fawcettii var. scabiosa Jenk. (teleomorph unknown); and (iii) sweet orange scab caused by E. australis Bitancourt \& Jenk. (anamorph S. australis Bitancourt \& Jenk.) (10). Subsequently, Tryon's scab was demonstrated to be caused by two pathotypes of E. fawcettii, and $S$. fawcettii var. scabiosa was not morphologically distinguishable from $E$. fawcettii $(9,11)$. Citrus scab is the most widely distributed disease, occurring in almost every area where rainfall conditions are conducive to infection. Sweet orange scab has been reported only in South America.

Whiteside $(12,13)$ differentiated two biotypes of E. fawcettii causing citrus scab

Corresponding author: J.-W. Hyun
E-mail: jwhyun@ @rda.go.kr

Accepted for publication 4 June 2001

Publication no. D-2001-0723-02R

(C) 2001 The American Phytopathological Society based on host range in Florida, which were subsequently designated as the Florida narrow host range (FNHR) and Florida broad host range (FBHR) pathotypes of citrus scab (11). The FBHR pathotype affects the leaves and fruit of lemon (Citrus limon (L.) Burm. f.), rough lemon ( $C$. jambhiri Lush), grapefruit (C. paradisi Macf.), sour orange (C. aurantium L.), Temple and Murcott tangors (C. sinensis (L.) Osbeck $\times C$. reticulata Blanco); and the fruit of sweet orange ( $C$. sinensis). The FNHR type attacks all of the above except sour orange, Temple tangor, and sweet orange fruit. Timmer et al. (11) used five differential hosts for determination of pathotypes of E. fawcettii and recognized four pathotypes: FBHR, FNHR, Tryon's, and Lemon, as well as sweet orange scab caused by E. australis. Studies have indicated that random amplified polymorphic DNA (RAPD) markers are useful for the identification and differentiation of races or pathotypes of many fungi $(2,3,5)$. Tan et al. (9) readily differentiated E. australis from the Florida and Australian biotypes of E. fawcettii by restriction analysis of the amplified internal transcribed spacers (ITS) of ribosomal DNA with several endonucleases, by sequencing of the ITS region, and by RAPD analysis.

Satsuma mandarin (C. unshiu (Macf.) Marc.) and yuzu (C. junos Sieb ex Tanaka) are commercially cultivated on Jeju Island.
Satsuma mandarin, which occupies over $95 \%$ of 26,000 ha devoted to citrus, is severely affected by scab. Kinkoji ( $C$. obovoidea Hort ex Tak.) and natsudaidai $(C$. natsudaidai Hayata), which are not commercially cultivated but are used for garden trees, are affected by scab, and disease is often severe on kinkoji. Determination of the taxonomic relationships and host ranges of the described species and pathotypes of citrus scab is important for regulatory purposes, breeding of disease-resistant cultivars, and in the selection of cultivars for use in various citrus areas. However, the distribution and host range of the species and pathotypes of citrus scab pathogens on Jeju Island in Korea have not been determined. Therefore, this study was carried out to compare the cultural and pathological characteristics among isolates of citrus scab pathogens in Jeju Island, and to determine the level of genetic variability among the isolates, pathotypes, and species by RAPD analysis.

\section{MATERIALS AND METHODS}

Isolates. Isolates from Jeju Island were collected from leaves or fruits of four citrus species: satsuma mandarin, yuzu, kinkoji, and natsudaidai in Jeju Island (Table 1). Isolations were made by disinfesting fruit for $1 \mathrm{~min}$ in $75 \%$ ethanol and then 1 min in $1 \%$ sodium hypochlorite followed by rinsing in sterile water. After drying, scab pustules were scraped with a scalpel to deposit flakes of diseased tissue onto half-strength PDA (12.0 g of potato dextrose broth and $15 \mathrm{~g}$ of agar in 1 liter of distilled water). Colonies recovered from the plates were derived from a small piece of a single pustule which theoretically is produced by a single conidium; therefore, cultures were not single spored.

Isolates of E. fawcettii were obtained from Florida and from Australia (M. Priest, New South Wales Agriculture, Orange, NSW). Isolates of E. australis were obtained directly from Argentina (S. M. Garrán, Instituto Naciónal de Técnologia Agropecúaria, Concordia, Entre Rios) or from the collection of M. Priest in Australia. All isolates were maintained on PDA slants.

Production of conidia. Conidia were produced by the method of Whiteside (13). Small pieces of mycelium (5 to $10 \mathrm{~mm}^{3}$ ) were removed from a 2- to 3-week-old 
culture on PDA, crushed in a plastic petri plate with a spatula, and resulting fragments stirred into liquid-modified Fries medium (12). Plates were incubated for 1 or 2 days at $27^{\circ} \mathrm{C}$. The plates were then washed three times with sterile, distilled water, and incubated overnight in the dark.

Pathogenicity. Pathogenicity was determined on leaves of the differential hosts previously described (11): rough lemon, grapefruit, sour orange, cleopatra mandarin (C. reshni Hort. ex Tan), plus satsuma mandarin and natsudaidai. Seedlings of these citrus species were grown in a greenhouse maintained at 18 to $33^{\circ} \mathrm{C}$. Plants were pruned to stimulate production of uniform flushes of new leaves and inoculated when leaves were one-quarter mature size by spraying with a suspension of $10^{6}$ conidia $/ \mathrm{ml}$. The plants were covered with plastic bags for $48 \mathrm{~h}$ for infection, and symptom severity was recorded when the leaves were mature. A plant was considered positive for infection if a clearly distinguishable scab lesion developed.

Pathogenicity tests on fruit were conducted by spraying the fruit 6 weeks after petal fall with a conidial suspension at $10^{6} / \mathrm{ml}$. In all, 5 to 10 fruit were used for each isolate. Fruit were covered with plastic bags for 7 days after inoculation and symptoms rated 30 days later. Pathogenic- ity tests were repeated at least once in almost all cases. All tests giving negative results were conducted at least three times.

RAPD assay. A total of 10 isolates of the E. fawcettii composed of FNHR and FBHR pathotypes from Florida and Jeju Island, 3 E. fawcettii isolates from Australia, 5 natsudaidai isolates, and 6 isolates of E. australis from Argentina were compared using RAPD analysis. Total genomic DNA of each fungal isolate was extracted from colonies grown on PDA according to the procedure described in Hyun et al. (6), which basically followed the method of Yoon (15), and amplified with 30 random 10-mer primers from Operon Primer Kit $\mathrm{P}$ and $\mathrm{X}$ (Operon Technologies, Alameda, CA) and 12 random 20-mer primers from SRILS UniPrimer Kit I (Seoulin Scientific Co., Seoul, Korea) designed from repetitive sequences of Korean red rice. Amplification reactions were done in a $25-\mu 1$ reaction mixture containing $2.5 \mu \mathrm{l}$ of $10 \times \mathrm{Taq}$ DNA polymerase reaction buffer (Promega Corp., Madison, WI), $2.5 \mathrm{mM} \mathrm{MgCl} 2,0.2$ $\mathrm{mM}$ each of dATP, dCTP, dGTP, dTTP, 0.2 $\mu \mathrm{M}$ of each primer, with approximately 5 ng of template DNA and 1 unit of Taq DNA polymerase (Promega Corp.). Each reaction was overlaid with two drops of sterile mineral oil. The polymerase chain reaction (PCR) was performed in a programmable thermocycler (Perkin-Elmer
Cetus thermal cycler, model 480), using an initial denaturation step of $95^{\circ} \mathrm{C}$ for $2 \mathrm{~min}$, followed by 40 amplification cycles of denaturation at $94^{\circ} \mathrm{C}$ for $30 \mathrm{sec}$, annealing at $40^{\circ} \mathrm{C}$ for the Operon Primer Kit or $50^{\circ} \mathrm{C}$ for the SRILS UniPrimer Kit for 1 min, extension at $72^{\circ} \mathrm{C}$ for $2 \mathrm{~min}$, and a final extension at $72^{\circ} \mathrm{C}$ for $10 \mathrm{~min}$. Primers that produced strong, reproducible PCR products (bands) were finally selected. After PCR, $12.0 \mu \mathrm{l}$ of the product were electrophoresed in a $1.4 \%$ agarose gel in Tris-acetate-EDTA (TAE) buffer for $2 \mathrm{~h}$ at $3 \mathrm{~V} / \mathrm{cm}$ and visualized by ethidium bromide staining. A 1-kb DNA Ladder (GeneRuler, MBI, Fermentas) was used for molecular weight markers. All RAPD PCR reactions were run at least twice with similar results.

Data analysis. Each profile was compared on the basis of the presence versus absence, indicated by 1 and 0 , respectively, of RAPD products of the same electrophoretic mobility. Relative relatedness among isolates was determined by multivariate analysis of similarity coefficients, and a matrix of similarity coefficients for each pair of isolates was constructed. A cluster analysis of the Jaccard similarity coefficients was performed with the unweighted pair-group method algorithm (UPGMA). All calculations were conducted using the computer program NTSYS-pc (8).

Table 1. Host, geographic origin, pathotypes, and pathogenicity of scab isolates from citrus on various citrus species in the greenhouse

\begin{tabular}{|c|c|c|c|c|c|c|c|c|}
\hline \multirow[b]{2}{*}{ Location, isolate ${ }^{b}$} & \multirow[b]{2}{*}{ Host $^{\mathrm{c}}$} & \multicolumn{6}{|c|}{ Pathogenicity $^{\mathrm{a}}$} & \multirow[b]{2}{*}{ Pathotype $^{\mathrm{d}}$} \\
\hline & & SM & $\mathbf{R L}$ & SO & GF & $\mathbf{C M}$ & $\overline{\mathrm{NDF}}$ & \\
\hline \multicolumn{9}{|l|}{ Jeju } \\
\hline SM 3-1, 24-1, Sang 2-1 & SM & + & + & + & + & + & - & FBHR \\
\hline SM $12-1,16-8$, X2-5 & SM & + & + & - & + & + & - & FNHR \\
\hline SM 12-2, 16-1, 16-4, 16-7, 24-4, 24-5, SJIN, MUD, Sang 1-1, Yeon-3 & SM & + & + & + & + & + & NT & FBHR \\
\hline$\underline{\text { Yuzu-3 }}$ & $\mathrm{YZ}$ & + & + & + & + & + & - & FBHR \\
\hline Yuzu-1, 2, 2a, Ryuzu-2, 5, SM 16-3, SM 12-5 & YZ & + & + & + & + & + & NT & FBHR \\
\hline $\mathrm{X} 1-5$ & KK & + & + & + & + & + & - & FBHR \\
\hline Ryuzu-1, Maru-1, 2, 3, 4 & KK & + & + & + & + & + & NT & FBHR \\
\hline $\mathrm{Na}-\underline{1},-\underline{2},-\underline{3},-4,-\underline{5},-\underline{6}$ & $\mathrm{NDF}$ & - & - & - & - & - & + & \\
\hline \multicolumn{9}{|l|}{ Florida } \\
\hline$\underline{\mathrm{Scott}}$ & Tem & + & + & - & + & + & NT & FNHR \\
\hline$\overline{\mathrm{S} 381} 62(70254),{ }^{\mathrm{e}} \mathrm{CC}-1$ & GF & + & + & - & + & + & NT & FNHR \\
\hline 70033 & Volk & + & + & - & + & + & NT & FNHR \\
\hline 70255, 70257, Russ-15, 5 Moak-1 & Tem & + & + & + & + & + & NT & FBHR \\
\hline$\overline{\mathrm{SCSK}}$ & SCSK & + & + & + & + & + & NT & FBHR \\
\hline \multicolumn{9}{|l|}{ Australia } \\
\hline${\underline{70027^{\mathrm{e}}}}$ & Lemon & NT & + & NT & NT & + & NT & Tryon's \\
\hline${\overline{70217^{e}}}^{\mathrm{e}}$ & Lemon & NT & + & NT & NT & - & NT & Lemon \\
\hline$\overline{70298} \mathrm{e}$ & Emp & NT & + & NT & NT & + & NT & Tryon's \\
\hline \multicolumn{9}{|l|}{ Argentina } \\
\hline$\underline{70041^{\mathrm{e}}}$ & Val & NT & - & - & - & NT & NT & $\begin{array}{l}\text { Elsinoe } \\
\text { australis }\end{array}$ \\
\hline$\underline{70212^{\mathrm{e}}}$ & SM & NT & - & - & - & NT & NT & E. australis \\
\hline$\overline{\mathrm{Ea}-2,3}$ & Val & NT & NT & NT & NT & NT & NT & E. australis \\
\hline$\overline{\text { Ea-1,4 }}$ & SM & NT & NT & NT & NT & NT & NT & E. australis \\
\hline
\end{tabular}

a Symbols: + = pathogenic, $-=$ nonpathogenic, and NT = not tested.

${ }^{\mathrm{b}}$ Underlined isolate numbers were those used in the random amplified polymorphic DNA assays. All five-digit isolate members beginning with 7 are from the collection of M. Priest (New South Wales Agriculture, Orange, Australia).

${ }^{\mathrm{c}} \mathrm{SM}=$ satsuma mandarin, $\mathrm{RL}=$ rough lemon, $\mathrm{SO}=$ sour orange, $\mathrm{GF}=$ grapefruit, $\mathrm{CM}=$ cleopatra mandarin, $\mathrm{NDF}=$ natsudaidai fruit, $\mathrm{YZ}=$ yuzu, $\mathrm{KK}=$ kinkoji, Val = Valencia sweet orange, Emp = Emperor mandarin, Tem $=$ Temple tangor, Volk = Citrus volkameriana Ten. and Pasq., and SCSK = Sun chu sha kat mandarin.

${ }^{\mathrm{d}} \mathrm{FNHR}=$ Florida narrow host range and FBHR $=$ Florida broad host range.

e Data from reference 10. 


\section{RESULTS}

Observations and cultural characteristics. Thirty-six isolates were recovered from four citrus species on Jeju Island. Scab was observed on only six fruit in about 400 trees of natsudaidai in eight surveyed locations. Scab pustules on infected natsudaidai fruit were similar in size, shape, and degree of elevation to those on satsuma mandarin, but were more reddish. Conidia of many isolates were examined for possible distinguishing characteristics. All were hyaline and variable in shape and produced buds. No size differences were apparent.

The characteristics of scab colonies on PDA were extremely variable even within the same isolate. All isolates typically formed very slow-growing, pulvinate, or raised and deeply fissured, gummy to mucoid colonies on PDA medium, but formed tomentose colonies in some cases. Tomentose colonies were found in cultures from all species but were more common among natsudaidai isolates. Gummy or mucoid colonies of isolates from natsudaidai did not differ from those of isolates from other citrus species, but tomentose colonies of isolates from natsudaidai were distinguishable from those from other citrus species. Tomentose colonies of isolates from natsudaidai produced relatively fastgrowing, radially sulcate colonies covered with whitish to grayish mycelium. Com-

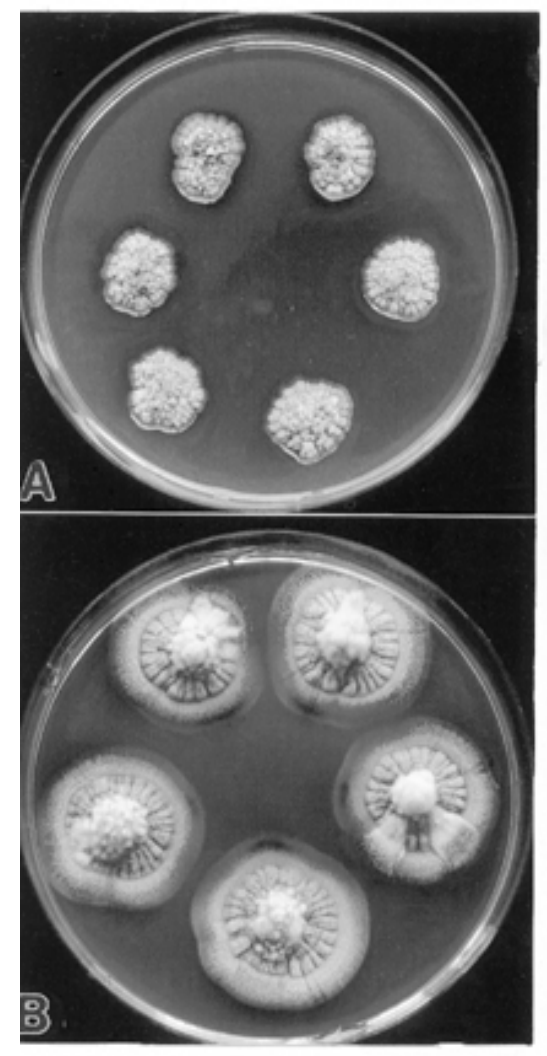

Fig. 1. Colony morphology of $\mathbf{A}$, colonies of Elsinoe fawcettii and $\mathbf{B}$, colonies of isolates from natsudaidai, cultured for 30 days on potato dextrose agar. pared with colonies of isolates from other citrus species, those isolates from natsudaidai were larger and more expansive (Fig. $1 \mathrm{~A}$ and $\mathrm{B}$ ). When isolates producing tomentose colonies were grown in liquid Fries medium, no cloudiness or other evidence of bacterial or yeast contamination was observed. No bacteria or yeast were found in microscopic examination of these isolates. Single-spore isolates of cultures $\mathrm{Na}-1$ and $\mathrm{Na}-2$ also produced tomentose colonies.

Whiteside (14) developed a semiselective medium for the isolation of E. fawcettii from citrus scab pustules by using dodine, and this medium has been usually used for isolation from host tissues. However, in our experiment, isolates of all pathotypes of E. fawcettii, as well as isolates of E. australis, grew well on PDA containing dodine at $400 \mu \mathrm{g}$ a.i./ml, but natsudaidai isolates did not grow on this medium.

Pathogenicity and pathotype. In pathogenicity tests with 30 isolates from satsuma mandarin, yuzu, and kinkoji on four citrus species, 27 isolates were pathogenic to satsuma mandarin, rough lemon, sour orange, grapefruit, and cleopatra mandarin, and thus were considered to be the FBHR pathotype of E. fawcettii. Three isolates were pathogenic to satsuma mandarin, rough lemon, grapefruit, and cleopatra mandarin, but produced no symptoms on sour orange (Table 1) and were considered to be the FNHR pathotype. Six isolates from natsudaidai were not pathogenic to leaves and fruits of satsuma mandarin, leaves of rough lemon, sour orange, grapefruit, cleopatra mandarin, or natsudaidai, but were only pathogenic to fruit of natsudaidai (Table 1).

RAPD analysis. Of the 10,20 , and 12 primers in Operon kit $\mathrm{P}, \mathrm{X}$, and SRILS UniPrimer kit I, 1, 10, and 5, respectively, led to amplification of PCR products, including at least one clear polymorphic product per primer. The number of polymorphic fragments produced with each primer varied from 1 to 10 for each isolate.

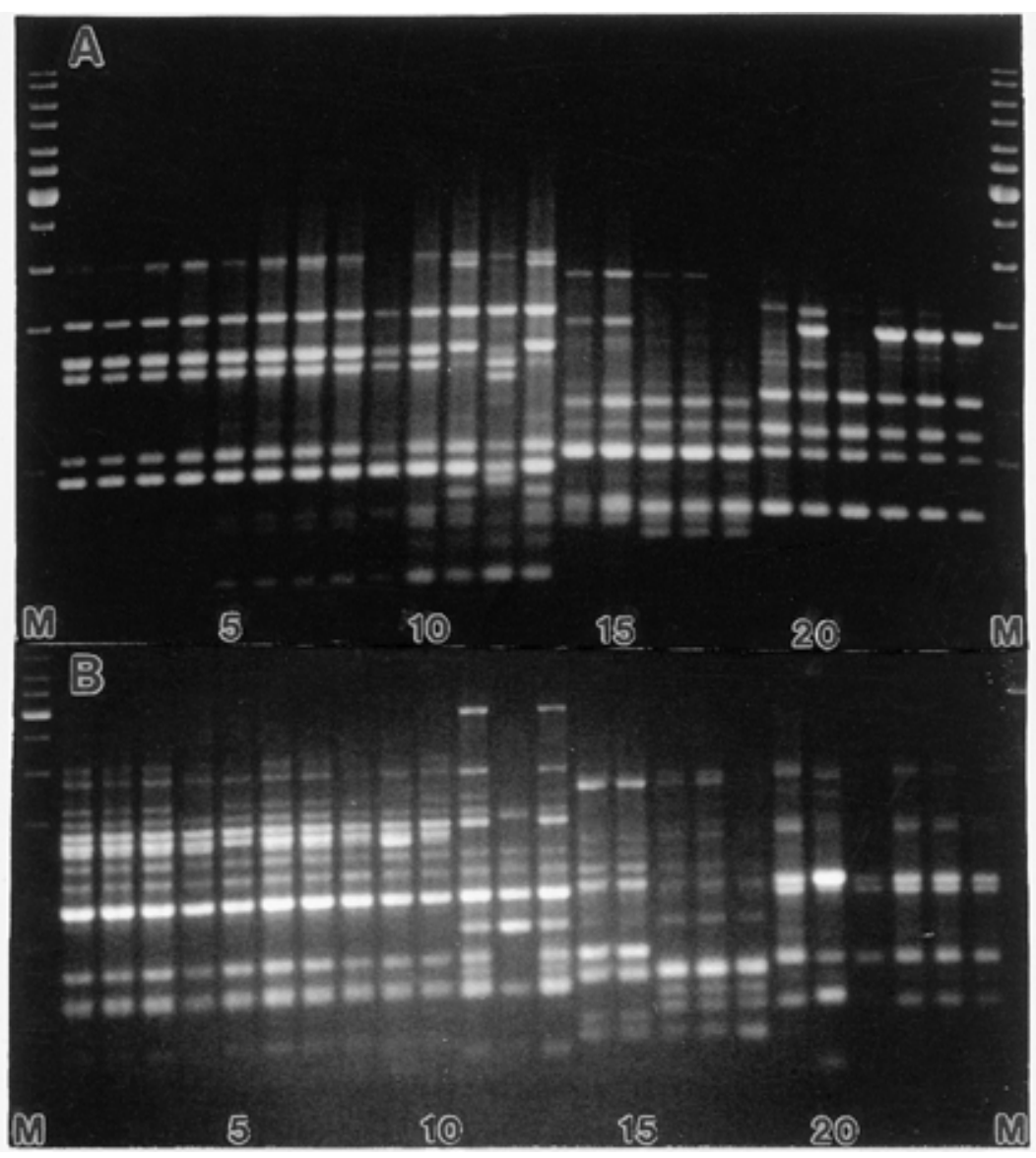

Fig. 2. A, Electrophoretic patterns for amplified fragments generated from isolates of citrus scab pathogens with random primer OPX-7 on a 1.4\% agarose gel. Lane M, marker DNA (1-kb ladder); lanes 1 to 5, Elsinoe fawcettii Florida narrow host range isolates SM 12-1, SM 16-8, and X2-5 from Korea and isolates Scott and CC-1 from Florida, respectively; lanes 6 to 10, E. fawcettii Florida broad host range isolates Maru-1, MUD, and Yuzu 3 from Korea and isolates Russ-15 and 70255 from Florida; lanes 11 to 13, E. fawcettii isolates of the Tryon's, lemon, and Tryon's pathotypes (70027, 70217, and 70298, respectively) from Australia; lanes 14 to 18, isolates from natsudaidai Na-5, -6, -1, -2, and -3, respectively, from Korea; lanes 19 to 24, E. australis isolates 70041, 70212, Ea-1, -2, -3, and -4, respectively, from Argentina. B, Electrophoretic patterns for amplified fragments generated from isolates of citrus scab pathogens with random primer OPX-13 on a $1.4 \%$ agarose gel. Lanes as described above. 
Two hundred twenty-six polymorphic fragments were used for cluster analysis. Based upon the presence or absence of amplification products ranging in size from 250 to $3,000 \mathrm{bp}$, all primers selected revealed polymorphisms useful for classifying $E$. fawcettii, natsudaidai isolates, and E. australis. Primers OPX-7 and 13 had especially distinct polymorphisms among pathotypes of E. fawcettii, E. australis, and natsudaidai isolates (Fig. 2A and B). However, no primers revealed distinct polymorphisms for classifying FNHR and FBHR pathotypes. The similarity coefficients among the isolates ranged from 0.42 to 1.00 , where 1.00 is identical. Ten isolates of the E. fawcettii composed of FNHR and FBHR pathotypes were clustered into one genetically distinct group, with similarity among isolates in the group ranging from 0.97 to 1.00 . However, Korean and Floridian isolates of E. fawcettii were differentiated by one marker with primer OPX-8 in the RAPD assay (data not shown). Two of three isolates of E. fawcettii from Australia were very close to each other, and the similarity value between the two isolates (70027 and 70298, Tryon's pathotype) and other pathotypes of E. fawcettii was 0.88 . The other Australian isolate (70217, lemon pathotype) was more distant, with a similarity value of 0.76 .

The similarity values among six isolates of E. australis from Argentina ranged from 0.89 to 1.00 ; of these, five isolates had very high similarity values (Fig. 3). The natsudaidai isolates were clustered into one genetically distinct group, with similarity among isolates in the group ranging from 0.90 to 1.00 . The similarity values between the natsudaidai isolates and E. fawcettii and E. australis were 0.41 and 0.58 , respectively (Fig. 3).

\section{DISCUSSION}

The three scab diseases were originally differentiated primarily on the basis of morphological and cultural characteristics such as spore size and colony color $(1,7)$. Tan et al. (9) readily differentiated three scab organisms using restriction analyses of the amplified ITS of ribosomal DNA with several endonucleases, RAPD analyses, and by sequence analysis of the ITS region. In the present study, the similarity coefficients between Australian and Floridian pathotypes of E. fawcettii were high, ranging from about 0.77 to 0.89 . However, Australian isolates of $E$. fawcettii were readily differentiated from Florida isolates by some RAPD markers. Jenkins (7) mentioned the need for further taxonomic study to determine whether S. fawcettii var. scabiosa (Tyson's scab) should be accorded specific rank distinct from $S$. fawcettii var. fawcettii, the conidial state of E. fawcettii. Tan et al. (9) strongly suggested that $S$. fawcettii var. scabiosa is conspecific with E. fawcettii based on indistinguishable conidia and the formation of spindleshaped conidia by both taxa. In the present study, the similarity coefficients between isolates of $S$. fawcettii var. scabiosa and E. fawcettii were relatively high compared with those between $E$. fawcettii and E. australis. This result supports classification of E. fawcettii and S. fawcettii var. scabiosa as different pathotypes of the same species.
Elsinoe spp. form two types of colonies: raised and gummy to mucoid colonies and tomentose colonies (16). E. australis and $E$. fawcettii have been differentiated on the basis of colony color $(1,4)$ and length-towidth ratios of conidia (4). Natsudaidai isolates produced two types of colonies, though it is not known under what conditions tomentose or gummy to mucoid colonies are formed. Natsudaidai isolates commonly produced tomentose colonies in the original isolations from the host as well as after five to six transfers. In this study, natsudaidai isolates were differentiated from other scab pathogens on the basis of colony characteristics and sensitivity to dodine.

Similarity of natsudaidai isolates to isolates of E. australis and E. fawcettii based on RAPD markers was low (0.57 and 0.42 , respectively). The five natsudaidai isolates were clearly clustered into one genetically distinct group, with similarity among isolates in the group ranging for 0.91 to 1.00 . The natsudaidai isolates had distinct colony morphology and may represent a different pathotype or other variant of E. australis or may be a distinct species. Therefore, a taxonomic study including natsudaidai isolates will be necessary to clarify the molecular, morphological, and cultural differences that exist among scab pathogens.

Even though isolates from both Korea and Florida were included in the RAPD analysis, the FBHR and FNHR isolates were clustered into one very close group, with similarity among isolates in the group ranging from 0.99 to 1.00 . The two pathotypes of E. fawcettii were not distinguishable by RAPD assay, but isolates from Jeju

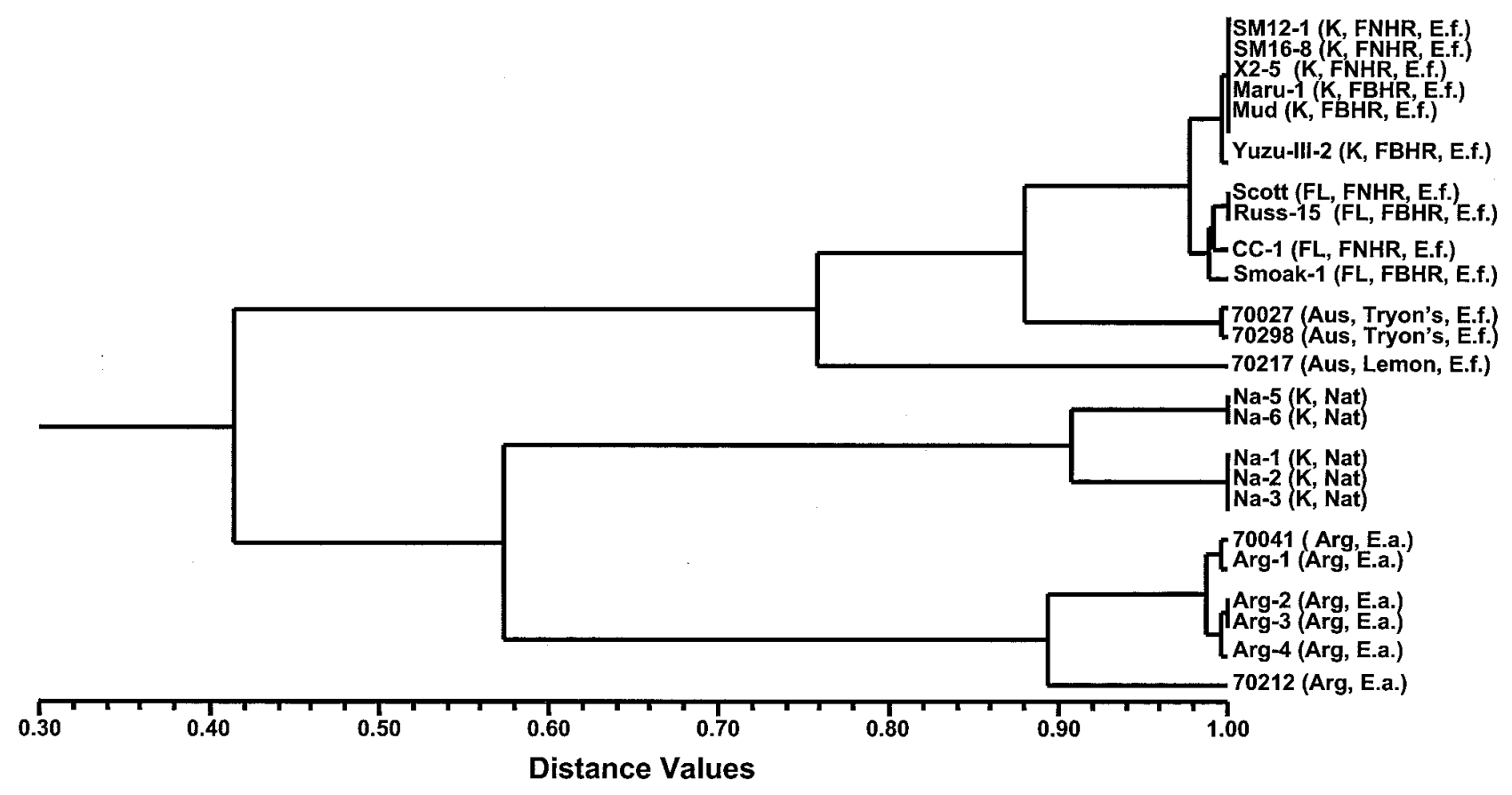

Fig. 3. Dendrogram of the random amplified polymorphic DNA data showing the relationships of Elsinoe isolates from citrus. E. f. $=$ Elsinoe fawcettii isolates from Korea (K), Florida (FL), or Australia (Aus); FNHR = Florida narrow host range pathotype; FBHR = Florida broad host range pathotype; Nat = isolates from natsudaidai in Korea; and E. a. = E. australis isolates from Argentina (Arg). 
and Florida were distinguished by one marker (data not presented).

The FBHR pathotype is widespread on Jeju Island. With the broad host range of this pathotype, it will not be possible to choose other mandarin cultivars to avoid scab. The other known pathotypes, such as those from Australia, are mostly pathogenic to lemons and would not be a regulatory concern in cultivation of satsuma mandarin. The importance of isolates from natsudaidai for other cultivars is uncertain until the entire host range of these isolates has been determined.

\section{ACKNOWLEDGMENTS}

We thank M. Priest and S. M. Garrán for supplying isolates of Elsinoe spp.

\section{LITERATURE CITED}

1. Bitancourt, A. A., and Jenkins, A. E. 1937. Sweet orange scab caused by Elsinoe australis. J. Agric. Res. 54:1-17.

2. Chen, X., Line, R. F., and Leung, H. 1993. Relationship between virulence variation and DNA polymorphism in Puccinia striiformis. Phytopathology 83:1389-1497.

3. Crowhurst, R. N., Hawthorne, B. T.,
Rikkerink, E. H. A., and Templeton, D. 1991. Differentiation of Fusarium solani f. sp. cucurbitae races 1 and 2 by random amplification of polymorphic DNA. Curr. Genet. 20:391-396.

4. Fantin, G. 1988. Caracterizacão Morfológica, Fisiológica e Patológica de Especies de Elsinoe em Citros. Universidade de Sao Paulo, Piracicaba, Brazil.

5. Goodwin, P. H., and Annis, S. L. 1991. Rapid identification of genetic variation and pathotype of Leptosphaeria maculans by random amplified polymorphic DNA assay. Appl. Environ. Microbiol. 57:2482-2486.

6. Hyun, J-W., and Clark, C. A. 1998. Analysis of Fusarium lateritium using RAPD and rDNA RFLP techniques. Mycol. Res. 102:1259-1264.

7. Jenkins, A. E. 1936. Australian citrus scab caused by Sphaceloma fawcettii scabiosa. Phytopathology 26:195-197.

8. Rohlf, F. J. 1998. NTSYS-pc, Numerical Taxonomy and Multivariate Analysis System version 2.0. Department of Ecology and Evolution, State University of New York, Stony Brook.

9. Tan, M. K., Timmer, L. W., Broadbent, P., Priest, M., and Cain, P. 1996. Differentiation by molecular analysis of Elsinoe spp. causing scab diseases of citrus and its epidemiological implications. Phytopathology 86:1039-1044.
10. Timmer, L. W. 2000. Scab diseases. Pages 31 32 in: Compendium of Citrus Diseases, 2nd ed. L. W. Timmer, S. M. Garnsey, and J. H. Graham, eds. American Phytopathological Society Press, St. Paul, MN.

11. Timmer, L. W., Priest, M., Broadbent, P., and Tan, M.-K. 1996. Morphological and pathological characterization of species of Elsinoe causing scab diseases of citrus. Phytopathology 86:1032-1038.

12. Whiteside, J. O. 1975. Biological characteris tics of Elsinoe fawcettii pertaining to the epidemiology of sour orange scab. Phytopathology 65:1170-1175.

13. Whiteside, J. O. 1978. Pathogenicity of two biotypes of Elsinoe fawcettii to sweet orange and some other citrus cultivars. Phytopathology 68:1128-1131.

14. Whiteside, J. O. 1986. Semiselective media for the isolation of Elsinoe fawcettii from citrus scab pustules. Plant Dis. 70:204-206.

15. Yoon, C. S. 1992. Molecular Systematics and Population Genetics of Hypoxylon truncatum sensu Miller using RAPD. Ph.D. thesis, University of Illinois, ChampaignUrbana.

16. Zeigler, R. S., and Lozano, J. C. 1983. The relationship of some Elsinoe and Sphaceloma species pathogenic on cassava and other Euphorbiaceae in Central and South America Phytopathology 73:293-300. 